\title{
Evaluation of Noxious Effect of Environmental Contaminants Using Zebrafish Model ${ }^{\dagger}$
}

\author{
Bashyam Praneetha ${ }^{1, *}$ \\ 1 Department of Biotechnology, Sathyabama Institute of Science and Technology, Jeppiaar Nagar, Sholinganallur, Chennai \\ 600119 \\ * Correspondence: bashyampraneetha@gmail.com; \\ $\dagger$ Presented at International e-Conference on Bioengineering for Health and Environment (ICBHE 2020)
}

Received: 5.07.2020; Revised: 10.07.2020; Accepted: 12.07.2020; Published: 15.07.2020

\begin{abstract}
Effects of the inorganic chemicals Calcium Fluoride $\left(\mathrm{CaF}_{2}\right)$ and Hexaflurosilicilic acid $\left(\mathrm{H}_{2} \mathrm{SiF}_{2}\right)$ have been studied due to its excessive usage in drinking water plants, glass manufacturing etc. Toxicity studies on Zebrafish embryos have been carried out for $\mathrm{CaF}_{2}$ and $\mathrm{H}_{2} \mathrm{SiF}_{2}$ during the embryonic developmental stages to observe the changes taken place during the growth, development. These changes can be observed in cell differentiation, larval movements, delay in hatching, and by the changes in behavior. Due to the ease with the transparency of zebrafish embryos, it can be observed and manipulated. In the field of early developmental studies, these zebrafish embryos have been vital because they have faster development by which the whole organs get developed in 3 days. Thus it plays a significant role in the discovery and analysis of changes in the developmental aspects of their teratology study. Toxicity study in Adults Zebrafish can be studied through the histology analysis where the cell damage and cell death due to fluorides and acid ions which may also lead to morphological changes due to this environmental pollutant. This toxicity study can be studied based on behavioral effects, LC50 determination, and immunohistochemistry of the brain to observe the developmental neurotoxicity. This study describes the effect of the inorganic chemicals is leading to developmental toxicity, cell deformities, and cell death with the high mortality rate in the In vivo Zebrafish model.
\end{abstract}

Keywords: Toxicity; Zebrafish embryos; teratology study; LC50.

(C) 2020 by the authors. This article is an open-access article distributed under the terms and conditions of the Creative Commons Attribution (CC BY) license (https://creativecommons.org/licenses/by/4.0/).

\section{Funding}

This research received no external funding.

\section{Acknowledgments}

This research has no acknowledgment.

\section{Conflicts of Interest}

The authors declare no conflict of interest. 